\title{
A Study on Sustainable Reutilization of C\&D Debris in the Construction of Traffic Barrier
}

\author{
S. Janani ${ }^{1} \mathrm{a}^{*}$, V. Ranjani ${ }^{2, \mathrm{~b}}, \mathrm{H}$. Ram Prithivi ${ }^{2, \mathrm{c}}$ and R. Poongundran ${ }^{2, \mathrm{~d}}$ \\ ${ }^{1}$ Assistant Professor, Department of Civil Engineering, Kongu Engineering College, Erode, Tamil \\ Nadu, India \\ ${ }^{2}$ UG Scholar, Department of Civil Engineering, Kongu Engineering College, Erode, Tamil Nadu, \\ India \\ *ajanani.civil@kongu.edu, branjaniv.17civil@kongu.edu, cramprithivih.17civil@kongu.edu, \\ dpoongundranr.17civil@kongu.edu
}

Keywords: C\&D debris, Recycling Techniques, Traffic Barriers, Sustainable Approach, Fine and Coarse Aggregate

\begin{abstract}
In India, the construction industry is growing at twice the world average. This leads to a significant accumulation of C\&D waste. This typically includes asphalt, steel, concrete, bricks, wood and other building materials. It is estimated on a conservative basis that over 25-30 million tons of C\&D waste is generated which clogs rivers, blocks traffic and occupies land / agricultural space which in turn creates pollution, solid waste production, discharge of dust and gas and leads to additional utilization of natural resources including non-renewable resources, thereby depleting the available resources. Only little amount of construction and demolition concrete debris is recycled or reused. Construction and demolition waste generation and handling issues are being focused to achieve sustainable goals. Based on this study, experimental investigations are carried out to evaluate the material properties and to study the strength characteristics and effect of partial replacement $(20 \%, 30 \%$ and $40 \%)$ of both fine and coarse aggregate obtained from construction and demolition waste (CDW) in the construction of intermediate road traffic concrete barriers.
\end{abstract}

\section{Introduction}

According to the Building Material Promotion Council, India generates an estimated 150 million tonnes of C\&D waste every year yet the official recycling capacity is a meagre 6,500 tonnes per day i.e. about one percentage. The growing population in the country and requirement of land for commercial purposes have reduced the availability of land for open dumping. Among the 3R's there-utilization is an important strategy for management of such waste in effective manner.

\section{Role of the Government:}

The Bureau of Indian Standards has allowed the use of concrete made from recycled material and processed C\&D waste. Also, the Construction and Demolition Waste Rules and Regulations, 2016 mandated the reuse of recycled material wherever possible. The need for C\&D waste management is even recognized by the Swatch Bharat Mission. Above all, the fast depleting reserves of conventional natural aggregate and river sand urge us to adopt the recycling technology and material. This mutually paves the way for reduced purchase of raw materials along with low transportation cost, reduced capital investment on raw materials with improved profits and less environmental impact. 


\section{Literature overview}

Table 1.Literature overview.

\begin{tabular}{|c|c|c|c|c|c|}
\hline \multicolumn{6}{|c|}{ LITERATURE STUDY } \\
\hline No. & \begin{tabular}{|l|} 
NAME OF THE \\
LITERATURE
\end{tabular} & YEAR & RECYCLED PRODUCT & TESTS CONDUCTED & TEST RESULTS \\
\hline 1 & $\begin{array}{l}\text { Use of Construction } \\
\text { Demolition Waste in } \\
\text { Pavement }\end{array}$ & 2017 & $\begin{array}{l}\text { Feasibility of }(\mathrm{CDW}) \text { for } \\
\text { improving the performance } \\
\text { of sub grade and sub base } \\
\text { layers in the road design }\end{array}$ & $\begin{array}{l}\text { Aggregate Impact Value Test } \\
\text { Crushing Value Test } \\
\text { Specific Gravity Test } \\
\text { Water Absorption Test } \\
\text { Loss Angeles Abrasion Test. } \\
\text { Marshall stability Test }\end{array}$ & $\begin{array}{l}\text { The aggregates are best suited for } \\
\text { the design of road pavement. } \\
\text { The Marshall Stability of } \\
\text { construction demolition wastes was } \\
\text { found } 10.15 \mathrm{KN} \text { which satisfies the } \\
\text { requirement for DBM course as per } \\
\text { given in MORTH specification. }\end{array}$ \\
\hline 2 & \begin{tabular}{|l} 
Reusability of \\
Construction \& \\
Demolition waste in \\
bricks
\end{tabular} & 2017 & $\begin{array}{l}\text { Bricks } \\
\text { Cement and fly ash - Binder } \\
\text { Recycled coarse and fine } \\
\text { aggregates }\end{array}$ & $\begin{array}{l}\text { Hardness test } \\
\text { Efflorescence test } \\
\text { Water absorption test } \\
\text { Compressive strength test }\end{array}$ & $\begin{array}{l}\text { Bricks have compressive strength of } \\
9.71 \mathrm{~N} / \mathbf{m m}^{\wedge} \mathbf{2} \text { is potentially at par } \\
\text { with the conventionally } \\
\text { manufactured common burnt clay } \\
\text { bricks. Hence highly recommended } \\
\text { for non-load bearing structure. }\end{array}$ \\
\hline 3 & $\begin{array}{l}\text { Preparation of Bricks } \\
\text { using Construction and } \\
\text { Demolition waste and } \\
\text { Sludge }\end{array}$ & 2018 & $\begin{array}{l}\text { Bricks with the ratio of } \\
3: 2: 3: 2 \\
\text { Fly ash : cement : sludge : C } \\
\& \text { D waste. }\end{array}$ & $\begin{array}{l}\text { Compressive strength } \\
\text { Bulk Density } \\
\text { pH content } \\
\text { Water Absorption }\end{array}$ & $\begin{array}{l}\text { This brick (recycled ) has a } \\
\text { potential to be used as instead of } \\
\text { normal bricks, except the pH value } \\
(6.7<8.5)\end{array}$ \\
\hline & $\begin{array}{l}\text { Experimental } \\
\text { investigation on effect } \\
\text { of demolished } \\
\text { aggregate in paving } \\
\text { block }\end{array}$ & 2018 & $\begin{array}{l}\text { Replacement of coarse and } \\
\text { fine aggregates in Paver } \\
\text { blocks }\end{array}$ & $\begin{array}{l}\text { Flexural strength test } \\
\text { Spilt tensile strength } \\
\text { Compressive strength test }\end{array}$ & $\begin{array}{l}\text { Use of } 50 \% \text { recycled aggregate } \\
\text { paving block shows good results } \\
\text { over fully replaced demolished } \\
\text { aggregate. } \\
\text { Mix : } 1: 2.71: 2.6 \text { (M30 grade) }\end{array}$ \\
\hline 5 & $\begin{array}{l}\text { Experimental Study on } \\
\text { Bricks by Using } \\
\text { Demolished } \\
\text { Construction Material }\end{array}$ & 2018 & $\begin{array}{l}\text { Bricks with } 20 \% \\
\mathrm{C} \text { and D debris }\end{array}$ & $\begin{array}{l}\text { Water absorption test } \\
\text { Compressive test }\end{array}$ & $\begin{array}{l}23.42 \mathrm{~N} / \mathbf{m m}^{\wedge} 2 \text { compressive } \\
\text { sttrength is obtained. }\end{array}$ \\
\hline 6 & $\begin{array}{l}\text { Study of Construction } \\
\text { and Demolition waste } \\
\text { for reuse and recycle }\end{array}$ & 2018 & Recycled aggregates & $\begin{array}{l}\text { Sieve analysis } \\
\text { Particle size distribution } \\
\text { Impact value test }\end{array}$ & $\begin{array}{l}\text { Recycled aggregate is in workable } \\
\text { condition and can be used for the } \\
\text { road construction purpose. }\end{array}$ \\
\hline & $\begin{array}{l}\text { Use of Construction } \\
\text { and Demolition Waste } \\
\text { as Partial Replacement } \\
\text { of Fine Aggregate for } \\
\text { Development of Paving } \\
\text { Block }\end{array}$ & 2018 & $\begin{array}{l}\text { C \& D debris as Partial } \\
\text { Replacement of Fine } \\
\text { Aggregate for Paver Block }\end{array}$ & $\begin{array}{l}\text { Compression strength test } \\
\text { Flexural strength test } \\
\text { Split tensile Test } \\
\text { Abrasion Test }\end{array}$ & $\begin{array}{l}\text { Higher compressive strength was } \\
\text { achieved when } 40 \% \text { to } 60 \% \\
\text { fine aggregate was replaced by } \\
\text { C\&D waste fine aggregate. }\end{array}$ \\
\hline 8 & $\begin{array}{l}\text { Reuse of Clay Brick } \\
\text { Waste in Mortar and } \\
\text { Concrete }\end{array}$ & 2020 & $\begin{array}{l}\text { Clay brick powder (CBP) } \\
\text { exhibits pozzolanic activity } \\
\text { and can be used as cement } \\
\text { replacement. } \\
\text { Recycled clay brick } \\
\text { aggregate (RBA) can be } \\
\text { used to substitute natural } \\
\text { coarse aggregate. }\end{array}$ & $\begin{array}{l}\text { Flexural strength test } \\
\text { Compressive strength }\end{array}$ & $\begin{array}{l}\text { The higher the replacement rates of } \\
\text { RBAs are, the greater the strength } \\
\text { loss was. The reduction in } \\
\text { compressive strength was } 44 \% \text { in } \\
\text { RBAC prepared with } 50 \% \text { RBAs } \\
\text { after } 28 \text { days. }\end{array}$ \\
\hline
\end{tabular}


There are numerous way for recycling the waste but the best is again using it without much change in its original form by retaining or strengthening its physical and chemical properties. Based on the literature study, re-utilization is one of the best disposal methods for C and D debris.

The Recycled products are summarized as follows,

- Recycled aggregates

- Bricks

- Paver blocks

- Sub - grade and sub - base layer

By analyzing the characteristics of the recycled products from the journals, it is acceptable to adapt the same methodology for the others construction elements. In our day to day, replacing a element should be economical and efficient and when it comes to Median Rigid Traffic Barrier, it satisfies both the above conditions and their strength criteria will match with the above mentioned products. And as we know roads are like nerves which connects every nodes of the region, the maximum utilization of $\mathrm{C}$ and $\mathrm{D}$ debris can be adapted through this method of traffic barrier construction.

\section{Standards for Traffic Barrier}

As per IRC 119-2015, the role of median traffic barrier is to protect the roadside traffic from both the sides. An important factor in the design of concrete barriers is impact load, the load which is acted suddenly upon the barrier during collision. They are intended to prevent the impact Head-on-collisions caused by out-of-control vehicles jumping across the medians. The main objective is that it must satisfy performance requirements at minimum total cost including initial and maintenance costs. The capability of the traffic barrier is to effectively redirect passenger cars and vans for locations with poor geometrics, high traffic volume and on-going constructions activities.

\section{Discussion}

It is evident from the table, that the products produced from $\mathrm{C}$ and $\mathrm{D}$ waste has the potential and criteria to be reused as per the Standards and IS codes. Impact load is the foremost factor to be considered in the design of concrete barriers, which a vehicle exerts over them upon collision. Jersey type barrier dimensions are as follows

\footnotetext{
○ Height - $813 \mathrm{~mm}$

- Base width - $610 \mathrm{~mm}$

○ Top width - $240 \mathrm{~mm}$
} 

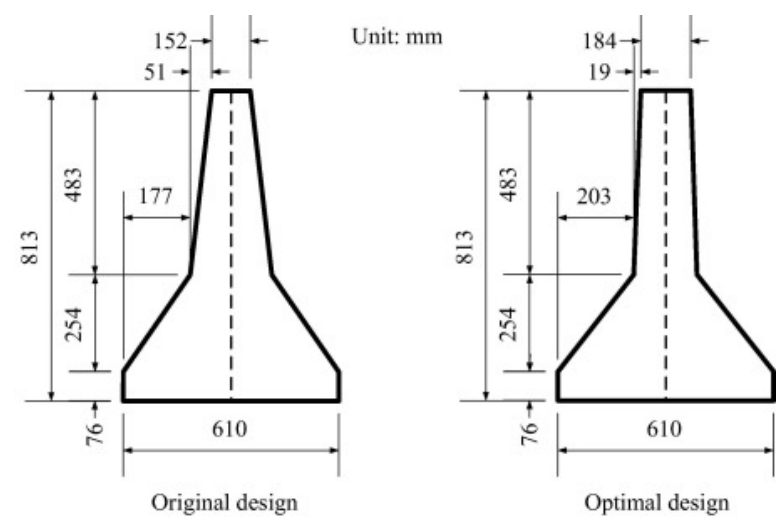

Figure 1. Cross section of Traffic Barrier.

These dimensions ensure the stability of concrete barriers during the collision time. The software utilized to create the analytical models is LS-DYNA as it can effectively simulate vehicle impact on concrete barriers. The key points from literature study are

O It is observed from the previous paper study, that maximum strength is achieved between the ranges when the replacement of fine aggregate is between $20 \%$ to $50 \%$.

- It is estimated that reutilization of $\mathrm{C}$ and $\mathrm{D}$ debris saves about $3.28 \%$ cost of concrete.

- It is learned from previous literature that the paver interlocks with demolished concrete waste along with $3 \mathrm{~cm}$ copper wire (e-waste) gave maximum compressive strength and least percentage water absorption.

The Strength characteristics are mainly governed by the mix design and proportions of the recycled material along with proper casting techniques. It is suggested that the minimum 28 day compressive strength of traffic barrier should be around $3000 \mathrm{lb} / \mathrm{in} 2$ (approximately $20 \mathrm{~N} / \mathrm{mm}^{\wedge} 2$ ). This strength can be determined by applying compressive load over the cubical specimen of size $150 \mathrm{~mm}$ x $150 \mathrm{~mm} \times 150 \mathrm{~mm}$.

\section{Experimental tests and results}

The $\mathrm{C}$ and $\mathrm{D}$ debris is collected from casting yard and crushed to required size. The debris is collected and segregated using IS $4.75 \mathrm{~mm}$ and $2.36 \mathrm{~mm}$ sieves. After this process, the specimen is tested for its specific gravity, particle size, aggregate strength test and water absorption test.

Specific gravity test results:

Table 2. Specific gravity test results.

\begin{tabular}{|c|c|c|}
\hline & COARSE AGG. & FINE AGG. \\
\hline NORMAL AGGREGATE & 2.9 & 2.69 \\
\hline RE-UTILIZED AGGREGATE & 2.94 & 2.8 \\
\hline STANDARD AGG. & 2.9 & 2.8 \\
\hline
\end{tabular}


Particle Size Distribution Analysis:

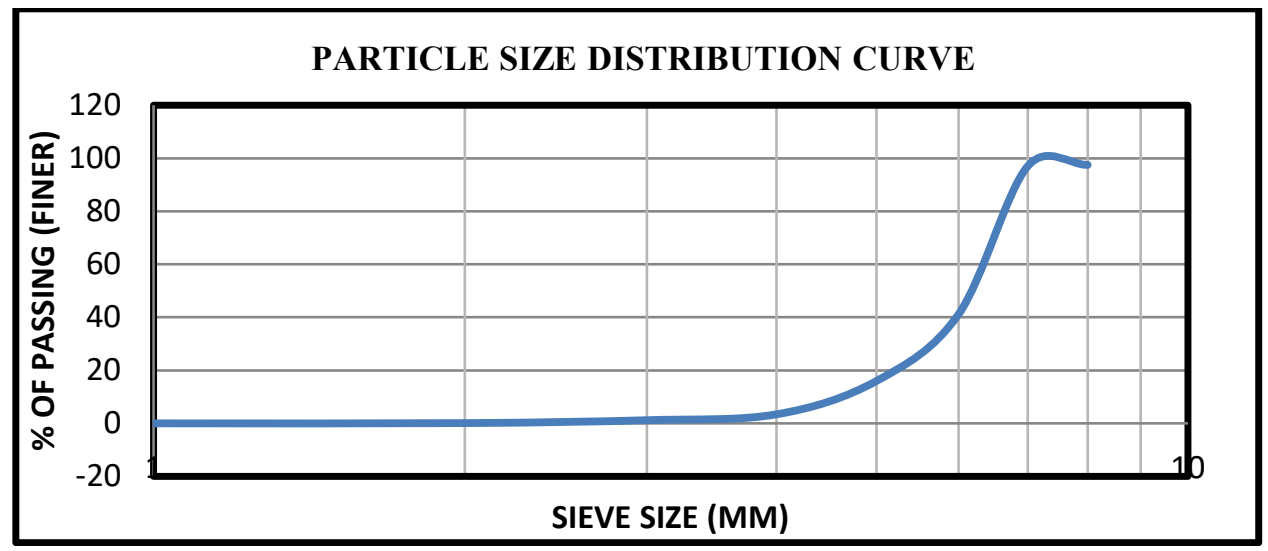

Figure 2. Gradation graph of $C \& D$ debris.

This curve indicates that the particles are in dense gradation which refers to a sample that is approximately of equal amounts of various sizes of aggregate i.e. An even curve on the gradation graph resulting in maximum Grain-to-grain contact.

Table 3. Particle size distribution analysis.

\begin{tabular}{|c|c|}
\hline SIEVE SIZE & \% FINER \\
\hline $0 \mathrm{~mm}$ & 0.1 \\
\hline $0.15 \mathrm{~mm}$ & 1.2 \\
\hline $0.30 \mathrm{~mm}$ & 3.4 \\
\hline $0.45 \mathrm{~mm}$ & 16 \\
\hline $1.18 \mathrm{~mm}$ & 41.1 \\
\hline $2.36 \mathrm{~mm}$ & 97 \\
\hline $4.75 \mathrm{~mm}$ & 97.5 \\
\hline
\end{tabular}

Aggregate strength test result:

Table 4. Aggregate Impact \& Crushing test Results.

\begin{tabular}{|c|c|c|}
\hline & IMPACT VALUE & CRUSHING VALUE \\
\hline NORMAL AGGREGATE & 11.02 & 8.9 \\
\hline RE-UTILIZED AGGREGATE & 20.44 & 18.03 \\
\hline AS PER IS 383:1970 & 45 & 45 \\
\hline
\end{tabular}


Water Absorption Test:

Table 5. Water Absorption test Results.

\begin{tabular}{|c|c|c|}
\hline & $\begin{array}{c}\text { REUTILISED } \\
\text { AGG. }(\mathrm{g})\end{array}$ & NORMAL AGG. $(\mathrm{g})$ \\
\hline $\begin{array}{c}\text { TOTAL DRY WEIGHT OF THE AGGREGATES } \\
\text { (W1) }\end{array}$ & 342 & 200 \\
\hline $\begin{array}{c}\text { WEIGHT OF THE SATURATED SPECIMEN } \\
\text { (W2) }\end{array}$ & 348 & 202 \\
\hline WEIGHT OF WATER ABSORBED (W2-W1) & 6 & 2 \\
\hline$\%$ OF THE WATER ABSORPTION (W3/W1) *100 & 1.75 & 1 \\
\hline
\end{tabular}

After the preliminary test, the materials are segregated separately. The M-40 grade of concrete is selected for cubical specimen testing. The mix design calculation is done as per IS 10262:2009. The cubes are casted with three different proportions of fine and coarse aggregates replacement with C\&D debris aggregates and they will be tested for its compressive strength at 7 and 14 days. The following table contains the volume of each mix for three cubes of dimensions $150 \mathrm{~mm}$.

Table 6. Mix Proportion (M40 grade \& Ratio - $1: 2.3: 3.8$ ) Details.

\begin{tabular}{|c|c|c|c|c|c|}
\hline \multirow{2}{*}{$\begin{array}{c}\text { Percentage } \\
\text { replacement } \\
\text { of coarse and } \\
\text { fine } \\
\text { aggregate }\end{array}$} & CEMENT & $\begin{array}{c}\text { NORMAL } \\
\text { FINE } \\
\text { AGGREGATE }\end{array}$ & $\begin{array}{c}\text { NORMAL } \\
\text { COARSE } \\
\text { AGGREGATE }\end{array}$ & $\begin{array}{c}\text { CDW } \\
\text { FINE } \\
\text { AGG. }\end{array}$ & $\begin{array}{c}\text { CDW } \\
\text { COARSE } \\
\text { AGG. }\end{array}$ \\
\hline $0 \%$ & 4.7385 & 10.803 & 18.057 & 0 & 0 \\
\hline $20 \%$ & 4.7385 & 8.6424 & 14.445 & 2.1606 & 3.6114 \\
\hline $30 \%$ & 4.7385 & 7.5621 & 12.6399 & 3.2409 & 5.4171 \\
\hline $40 \%$ & 4.7385 & 6.4818 & 10.8342 & 4.3212 & 7.2228 \\
\hline
\end{tabular}

The Slump value is between $80-100 \mathrm{~mm}$. Since we can assure the strength characteristics from the previous literature study, we can adapt the same process for the construction of Median Rigid Traffic Barrier.

\section{Conclusion}

The best way to reduce the impact of $\mathrm{C}$ and $\mathrm{D}$ waste is to re-utilize it in construction sector itself so as to minimize its effect over natural resources. The major demerit noted during literature study is the age of the concrete debris i.e., the age of building from which the CDW is extracted as it plays a vital role in achieving the strength characteristics. In order to eliminate this demerit, debris from the building built during past decade is to considered for analysis \& experimental test procedures. The above factor and experimental inferences will be considered while casting the cubical specimens even though the merits outweigh the demerits. The cubical specimens pertained to 
above mix proportions will be tested for its compressive strength ( $7 \& 14$ days strength) and future analysis will be done accordingly.

\section{References}

[1] Avinash M, Vishal K, Dnyaneshwar G, Vikram G, Sachin M and Prof Nigade Y M 2018 Preparation of Bricks using Construction and Demolition waste and Sludge Vol. 6 Issue 3 IJIRCCE ISSN (Online): 2320-9801[2] Shivkumar H, Rohit M. Shinde, Vaishnavi B and Tejashree G 2018 Experimental Investigation On Effect Of Demolished Aggregate In Paving Block Vol. 5 Issue 7 JETIR (ISSN-2349-5162)

[3] Vishal V P, Vinayak B K, Avadhut K and Akash K 2017 Use of Construction Demolition Waste in Pavement Vol. 4 Issue 12 IJIRCCE ISSN: 2350-0328

[4] Mohit A and Amit K 2017 Reusability of Construction \& Demolition waste in bricks Vol.4 Issue 12 IRJET e-ISSN: 2395-0056

[5] Yeotikar V U, Kulkarni G A, Syed Nadeem, Bhosale N M and Kokare D R 2018 Experimental Study on Bricks by Using Demolished Construction Material Vol.15 Issue2 JASRAE E-ISSN: 2230-7540. https://doi.org/10.29070/15/56790

[6] Makegaonkar A R, Dange P S and Waghmode R B 2018 Study of Construction and Demolition waste for reuse and recycleVol. 5 Issue 07 IRJET e-ISSN: 2395-0056

[7] Mahesh T, Krutika P, Priyanka N and Aditya P 2018 Use of Construction and Demolition Waste as Partial Replacement of Fine Aggregate for Development of Paving BlockVol.15Issue 2 JASRAE E-ISSN : 2230 -7540

[8] IRC 1192015 - Guidelines for traffic safety barrier 